\title{
Effects of physiological levels of the green tea extract epigallocatechin-3-gallate on breast cancer cells
}

\section{Li Zeng, Jeff M. P. Holly and Claire M. Perks*}

IGFs and Metabolic Endocrinology Group, School of Clinical Sciences, Southmead Hospital, University of Bristol, Bristol, UK

\section{Edited by:}

Haim Werner, Tel Aviv University,

Israel

\section{Reviewed by:}

Sue Mei Firth, The University of

Sydney, Australia

Ronit I. Yarden, Georgetown

University, USA

*Correspondence:

Claire M. Perks, IGFs and Metabolic Endocrinology Group, School of

Clinical Sciences, Southmead Hospital, University of Bristol,

Learning and Research Building, 2nd

Floor, Bristol BS10 5NB, UK

e-mail: claire.m.perks@bristol.ac.uk
Physiological concentrations of the green tea extract epigallocatechin-3-gallate (EGCG) caused growth inhibition in estrogen receptor $\alpha(E R \alpha)$-positive MCF7 cells that was associated with down-regulation of the $\mathrm{ER} \alpha$ and reduced insulin-like growth factor binding protein-2 abundance and increased protein abundance of the tumor suppressor genes p53/p21. In contrast to MCF7 cells that have wt p53, EGCG alone did not change cell proliferation or death significantly in another ER $\alpha$-positive cell line T47D that possesses mutant p53. EGCG increased ER $\alpha$ protein levels and as a consequence, the cells responded significantly better to an ER $\alpha$ antagonist tamoxifen (TAM) in the presence of EGCG. EGCG significantly increased cell death in an ER $\alpha$-negative cell line, MDA-MB-231 that also possesses mutant p53. EGCG significantly increased the ER $\alpha$ and insulin-like growth factor-I receptor levels and thereby enhanced the sensitivities of the cells to TAM and a blocking antibody targeting the insulin-like growth factor-1 receptor ( $\alpha$ IR3). In contrast to MCF7,T47D and MDA-MB-231 breast cancer cells that exhibited significant changes in key molecules involved in breast growth and survival upon treatment with physiological levels of EGCG, the growth, survival, and levels of these proteins in non-malignant breast epithelial cells, MCF10A cells, were not affected.

Keywords: EGCG, breast cancer, physiological, green tea, drug sensitivity

\section{INTRODUCTION}

Tea originated from China and has been produced and consumed for thousands of years. Due to different manufacturing methods, tea is produced in different forms. Green tea is made from fresh tea leaves (Camellia sinensis). Tea is the most widely consumed beverage next to water and provides a source of the well-known polyphenols, which are associated with a reduction in cancer risk (1). After steaming or pan-frying, enzymes are inactivated to prevent the oxidation of tea polyphenols, which are also called catechins. Catechins account for $30-40 \%$ of the dry weight of the solids in brewed green tea. There are four major catechins in green tea: (-)-epigallocatechin-3-gallate (EGCG), (-)-epigallocatechin (EGC), (-)-epicatechin gallate (ECG), and (-)-epicatechin (EC) (2). EGCG is the most abundant and biologically active polyphenolic catechin in green tea, and exerts multiple effects in humans. A variety of laboratory experiments, animal models, and epidemiology studies indicate the protective effects of many dietary agents against tumorigenesis, including EGCG (3). While the cancer preventive effects of green tea have been well established in animal models, its activity in humans is still controversial (4).

Breast cancer is now the most common cancer in developed countries. Despite decreased mortality due to improved prevention, detection by use of screening mammography and therapy options including endocrine therapy, incidence of breast cancer is still increasing. About one in eight (12\%) women in the US will develop invasive breast cancer during their lifetime (American Cancer Society ${ }^{1}$ ). In the last 10 years, female breast cancer

\footnotetext{
${ }_{1}$ www.cancer.org
}

incidence rates in the UK have increased by $6 \%$ (Cancer Research UK). Even in countries that used to have lower incidences of breast cancer, such as Japan and China, have observed increases in breast cancer incidence due to the adoption of a more westernized life style (5).

The major issue with the majority of research studying the effects of EGCG is that the levels of EGCG are super-physiological (from 20 to $200 \mu \mathrm{M}$ ) and such concentrations cause cytotoxic effects to normal cells, potentially causing unwanted side effects. A physiological serum concentration of EGCG $(<10 \mu \mathrm{M})$ can be achieved by drinking a couple of cups of green tea or taking a tablet supplement $(6,7)$, and the effects of these doses have not been well investigated.

Among many other cancers, EGCG has been found to inhibit cancer development in lung (8) (10-40 $\mu$ M EGCG) (9) (262 $\mu \mathrm{M}$ EGCG), prostate (10) (20-80 $\mu \mathrm{M}$ EGCG), colon (11) $(20 \mu \mathrm{M}$ EGCG), skin (12) (21-87 $\mu$ M EGCG), and breast cancers (13) (87-131 $\mu \mathrm{M}$ EGCG). A variety of mechanisms have been proposed as to how EGCG imparts its chemo-preventive effects, including inhibition of MAP-kinase, AP-1 (14), NFkB, angiogenesis, invasiveness, metastasis (15), and DNA methyl-transferase (DNMT) (16); induction of apoptosis; modulation of cell cycle checkpoint controls (8); transcription factor expression; and receptor-mediated functions (17). A recent study showed that with MCF7 and MDA-MB-231 cells, EGCG and a pro-drug of EGCG (pEGCG, EGCG octaacetate) caused hypomethylation of human telomerase reverse transcriptase (hTERT) gene via inhibition of histone deacetylase (HDAC) and histone acetyltransferase (HAT) activity. Demethylation of hTERT established a transcription repressing environment to prevent aberrant hTERT 
expression and lead to tumor suppression (18). pEGCG was synthesized by modulation of hydroxyl groups with peracetate groups to enhance the bioavailability and stability of EGCG. The same group also reported that combining EGCG and a HDAC inhibitor trichostatin (TSA) synergistically re-activated a functional estrogen receptor in MDA-MB-231 cells via altering the binding transcription repressor complex $\mathrm{pRb} 2 / \mathrm{p} 130$ E2F4/5-HDAC-DNMT1-SUV39H1 to the estrogen receptor $\alpha(\mathrm{ER} \alpha)$ promoter. This induction of $\mathrm{ER} \alpha$ expression could sensitize ER $\alpha$-negative breast cancers to anti-hormone therapy (19).

In this study, we aimed to assess if physiological concentrations of EGCG affected cell growth, cell death, and altered key molecules [insulin-like growth factor-1 receptor (IGF-1R), ER, and HER2] that have been implicated in regulating these processes and if such changes influenced the sensitivity to agents targeting breast cancer cells.

\section{MATERIALS AND METHODS}

All chemicals were purchased from Sigma (Gillingham, Dorset, UK) unless otherwise stated. $\alpha$ IR3 was bought from Calbiochem, Nottingham, UK, and herceptin was a kind gift from AstraZeneca, Cheshire, UK.

\section{CELL CULTURE}

The estrogen receptor negative human breast cancer cell line MDA-MB-231 was purchased from ECACC. The estrogen receptor positive human breast cancer cell lines MCF7 and T47D and the relatively normal breast epithelial cell line MCF10A were obtained from ATCC. Cells were maintained in growth media $(\mathrm{GM})$ at $37^{\circ} \mathrm{C}$ and $5 \% \mathrm{CO}_{2}$ in a humidified incubator. Growth medium for MCF10A consisted of a 1:1 mixture of Ham's F12 medium and Dulbecco's modified Eagle's medium with $2.5 \mathrm{mM}$ L-glutamine (DMEM:F12, Gibco, Paisley, UK), 5\% horse serum (Gibco, Paisley, UK), 20 ng/ml EGF (Calbiochem, Nottingham, UK), $100 \mathrm{ng} / \mathrm{ml}$ cholera toxin, $10 \mu \mathrm{g} / \mathrm{ml}$ insulin (Novo Nordisk, West Sussex, UK), and $0.5 \mu \mathrm{g} / \mathrm{ml}$ hydrocortisone. MCF7, T47D, and MDA-MB-231 cells were cultured in DMEM supplemented with 10\% fetal bovine serum (FBS). All GM contain penicillin $(50 \mathrm{IU} / \mathrm{ml})$, streptomycin $(50 \mathrm{IU} / \mathrm{ml})$, and L-glutamine $(2 \mathrm{mM})$. Experiments were performed in serumfree media (SFM) [DMEM:HamsF12 supplemented with sodium bicarbonate $(0.12 \%)$, BSA $(0.02 \%)$, apo-transferrin $(0.1 \mathrm{mg} / \mathrm{ml})$, penicillin $(50 \mathrm{IU} / \mathrm{ml})$, streptomycin $(50 \mathrm{IU} / \mathrm{ml})$, and L-glutamine $(2 \mathrm{mM})]$. Cells were seeded onto 6- or 24-well plates in GM and transferred to SFM $24 \mathrm{~h}$ later. Dosing was performed after $24 \mathrm{~h}$ in SFM. Cells were placed into fresh SFM and treated as detailed in the figure legends.

\section{CELl COUNTING}

Both attached and floating cells were collected and prepared for counting using a hemocytometer. Cells were mixed with trypan blue dye to distinguish live and dead cells. Cells were counted from which total cell number and the percentage of dead cells relative to control were calculated.

\section{TRITIATED THYMIDINE INCORPORATION}

Proliferation was also measured using [3H]-thymidine incorporation. $0.1 \mu \mathrm{Ci}$ of $\left[{ }^{3} \mathrm{H}\right]$-thymidine (Perkin Elmer Beaconsfield, Bucks, UK) was added to the cells for the last $4 \mathrm{~h}$ of treatment. Cells were then washed in 5\% trichloroacetic acid (TCA) for $10 \mathrm{~min}$ at $4^{\circ} \mathrm{C}$, followed by lysing in $1 \mathrm{M}$ sodium hydroxide for $1 \mathrm{~h}$ at room temperature. Lysates were mixed with ultima gold liquid scintillation cocktail (Perkin Elmer Beaconsfield, Bucks, UK) and incorporated counts were measured using a Beckman Scintillation Counter LS6500. Data were recorded as disintegrations per minute (DPM).

\section{WESTERN BLOTTING}

Cell lysates and media were run on 12\% SDS-PAGE gel and proteins transferred to a Hybond-C nitrocellulose membrane (GE Healthcare, Bucks, UK). Proteins were probed with anti-insulinlike growth factor binding protein-2 (IGFBP-2) 1:1000 (sc-6001 Santa Cruz); anti-ER $\alpha$ 1:750 (sc-73479 Santa Cruz, TX, USA); anti-PARP 1:1000 (556494 BD, Oxford, UK); anti-GAPDH 1:5000 (MAB 374 Millipore, Darmstadt, Germany); anti- $\alpha$-tubulin 1:5000 (ABJ1178 Autogen Bioclear, Wiltshire, UK); anti-Her2 1:1000 (\#2248 Cell Signaling, Hertfordshire, UK); anti-IGF-I receptor (IGF-IR) 1:1000 (D23H3 Cell Signaling, Hertfordshire, UK); antip53 1:1000 (sc-126 Santa Cruz, TX, USA); anti-p21 1:2000 (05345 Upstate Biotechnology, New York, NY, USA); or anti- $\beta$-actin 1:10000 (A5441 Sigma-Aldrich, Gillingham, Dorset, UK) following the manufacturer's instructions. Secondary antibodies were diluted in 5\% milk-TBST (20 mM Tris, $136 \mathrm{mM}$ sodium chloride, $0.1 \%$ Tween-20, $\mathrm{pH} 7.4$ ) and proteins visualized using supersignal west dura ECL solution (Thermo Fischer, Ulm, Germany) and the UVP Chemi-Doc-IT imaging system (Bio-Rad, Hertfordshire, UK), as described previously (20).

\section{RIA}

IGF-II was measured in MDA-MB-231 cell conditioned media by RIA as described previously (21).

\section{STATISTICAL ANALYSIS}

The data were analyzed with SPSS 12.0.1 for Windows using oneway ANOVA followed by least significant difference (LSD) post hoc test. A statistically significant difference was considered to be at $p<0.05$.

\section{RESULTS \\ EGCG AT PHYSIOLOGICAL CONCENTRATIONS INHIBITED CELL PROLIFERATION AND INCREASED CELL DEATH OF BREAST CANCER CELLS}

It has been reported that physiological, achievable serum concentration of EGCG is not higher than $1 \mu \mathrm{M}(22-24)$ or up to $7 \mu \mathrm{M}$ with a supplement (25). To analyze whether these physiological levels of EGCG have any impact on breast cancer cell proliferation, we assessed doses of EGCG up to $1 \mu \mathrm{M}$ in ER $\alpha$-positive breast cancer cell lines, MCF7 (Figure 1A), T47D (Figure 1B), and an ER $\alpha$-negative cell line MDA-MB-231 (Figure 1C). The percentages of total cell number compared to the control samples are shown. With $1 \mu \mathrm{M}$ EGCG, growth inhibition was observed in MCF7 (28\%, $p<0.01)$ and MDA-MB-231 (25\%, $p<0.05)$ cells, 


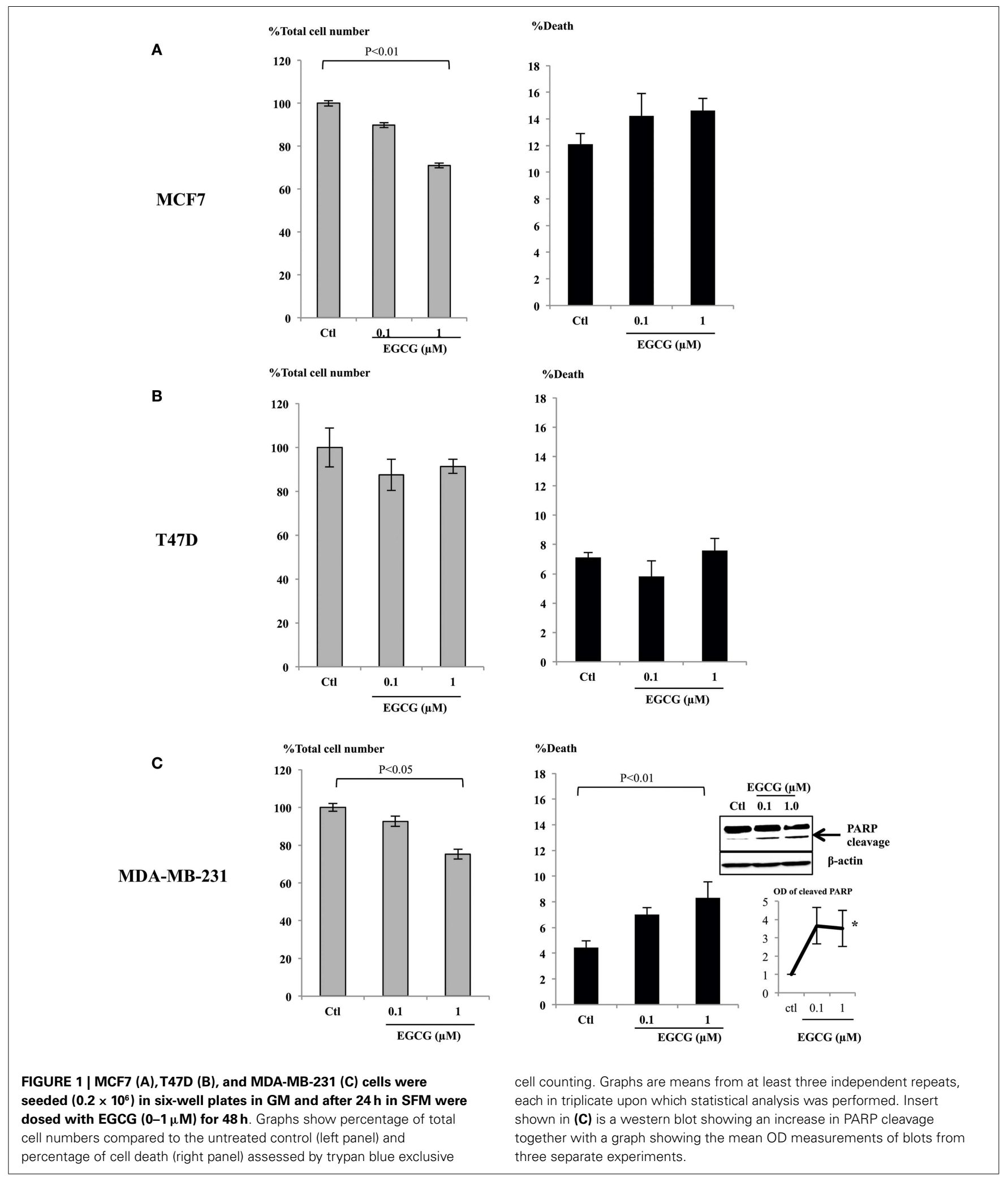

but cell growth was not significantly affected in T47D (8\%) cells. While no significant increase in cell death was achieved with $1 \mu \mathrm{M}$ EGCG in MCF7 or T47D cells, EGCG triggered a doubling in cell death $(p<0.01)$ in MDA-MB-231 cells, compared to untreated cells. We confirmed this was apoptotic cell death by showing an increase in PARP cleavage at 0.1 and $1 \mu \mathrm{M}$ (insert Figure 1C). 
PHYSIOLOGICAL CONCENTRATIONS OF EGCG INCREASED ER $\alpha$ AND IGF-IR ABUNDANCE IN MDA-MB-231 CELLS AND SENSITIZED THEM TO TAMOXIFEN AND AN IGF-IR INHIBITOR ( $\alpha$ IR3)

In order to further understand the effects of EGCG in MDA-MB231 cells, we assessed changes in the abundance of the IGF-IR and the ER $\alpha$ following treatment with EGCG. EGCG $(1 \mu \mathrm{M})$ caused an increase in their expression (Figure 2A): a $1.42(p<0.05)$ and $1.67(p<0.005)$ fold increase, respectively, compared to untreated controls (Figure 2B). We also observed that levels of HER2 were undetected and unaffected following treatment with EGCG (data not shown). We also found that the MDA-MB-231 cells secreted approximately $30 \mathrm{ng} / \mathrm{ml} \mathrm{IGF-II} \mathrm{as} \mathrm{measured} \mathrm{by} \mathrm{RIA.}$

We then tested the sensitivity of MDA-MB-231 cells to TAM and $\alpha$ IR3, which blocks ER $\alpha$ and IGF-IR pathways, respectively (Figure 2C). Initial experiments looking at the effects of EGCG were examining changes in cell number and cell death and therefore we used cell counting. In addressing the effects on the response to TAM and $\alpha$ IR3, as these affect growth but do not induce apoptosis at the doses used, we used thymidine incorporation as a more sensitive measure of changes in cell proliferation. Due to low level of the ER $\alpha$ and IGF-IR basally, as anticipated, MDA-MB-231 cells did not respond to TAM or $\alpha$ IR3 in terms of cell proliferation. But with pre-treatment of $1 \mu \mathrm{M}$ EGCG, TAM and $\alpha$ IR3 inhibited cell growth by $34 \%(p<0.01)$ and $21 \%(p=0.02)$, respectively.

\section{TREATMENT WITH EGCG INCREASED THE PROTEIN ABUNDANCE OF ER $\alpha$, Her2, AND IGFBP-2 IN T47D CELLS AND SENSITIZED THEM TO TAMOXIFEN, BUT NOT TO HERCEPTIN}

With T47D cells, EGCG at the physiological concentrations increased the abundance of $\mathrm{ER} \alpha$, Her2, and IGFBP-2 protein

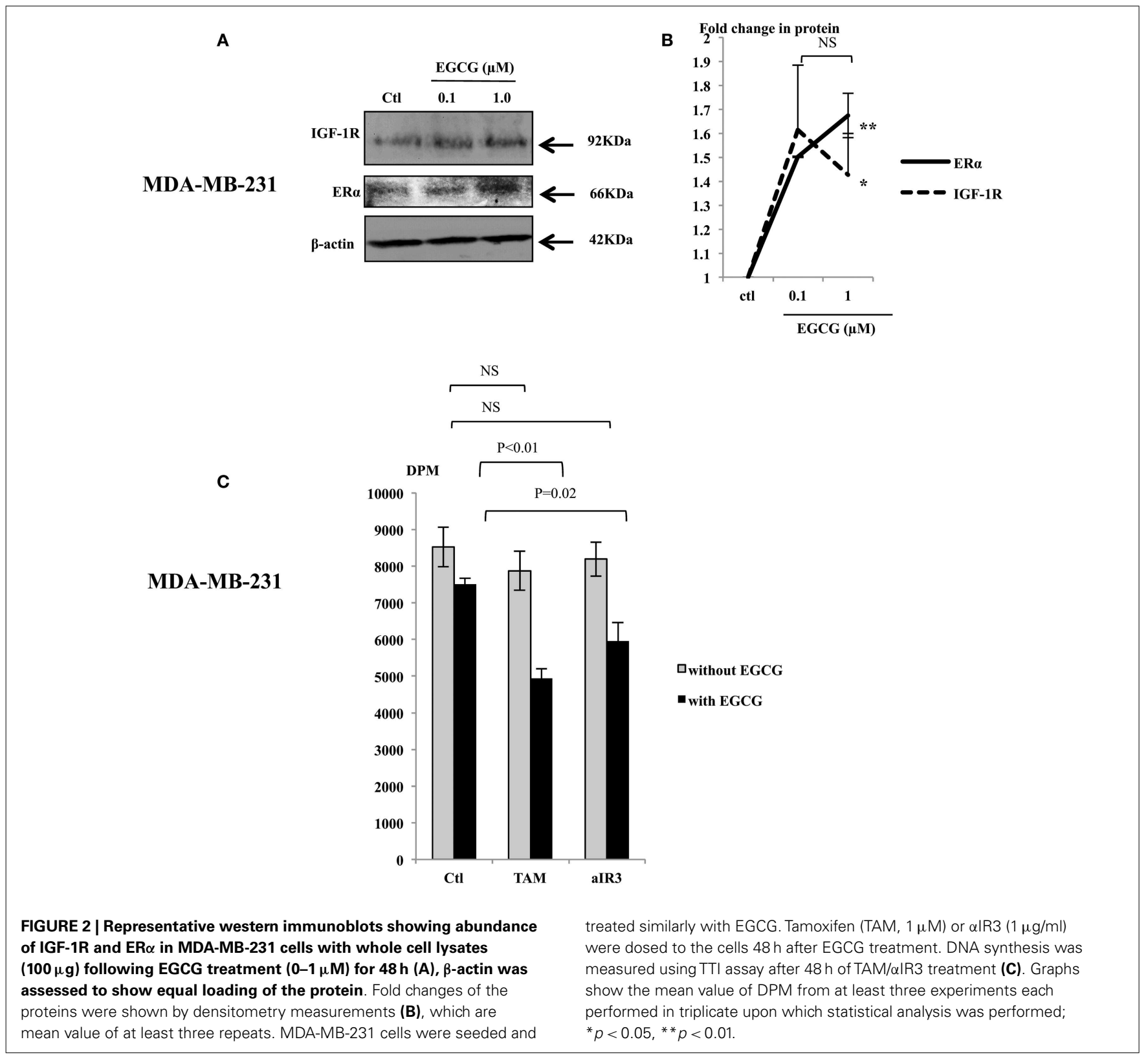




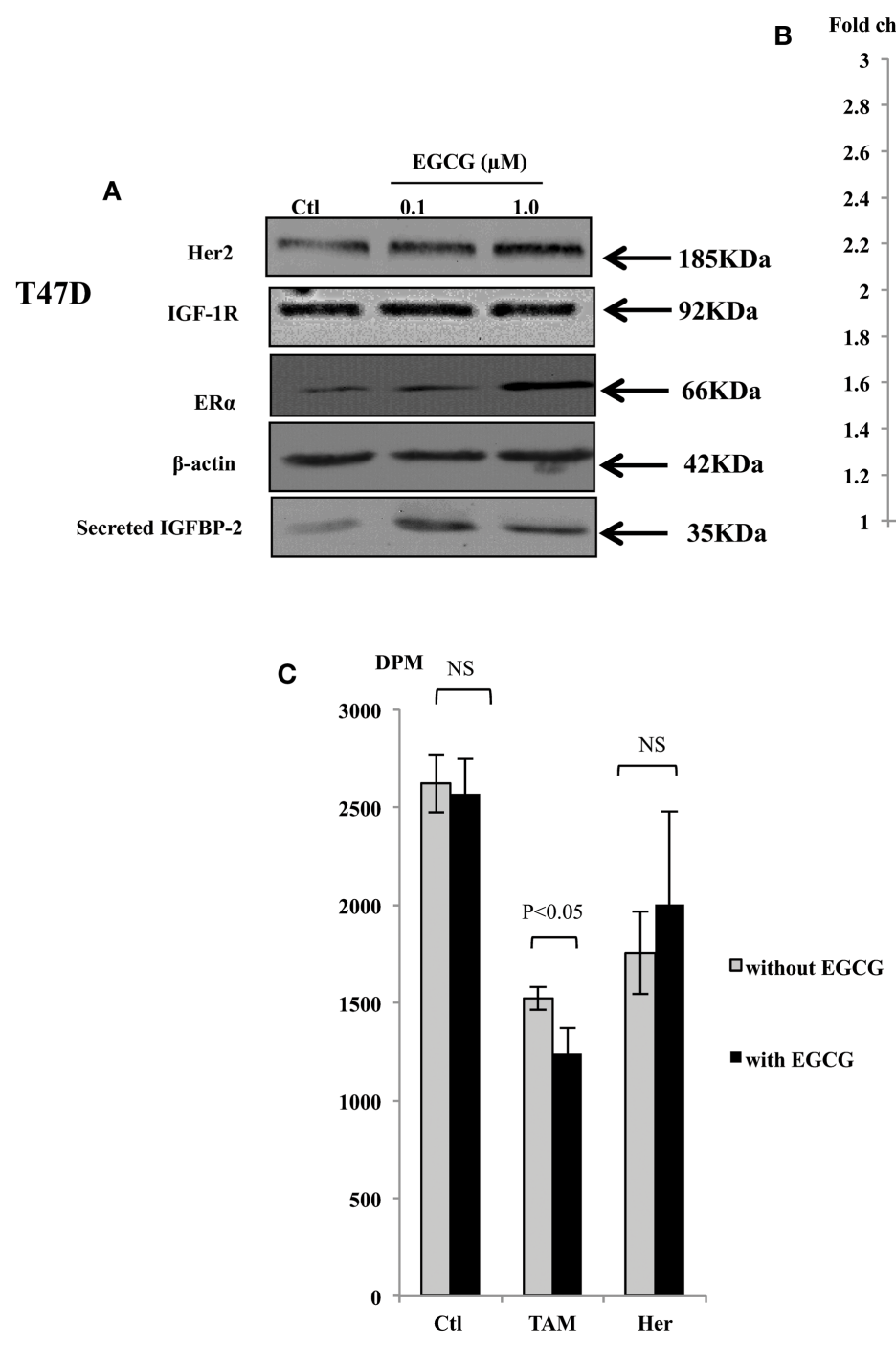

FIGURE 3 |Western immunoblot showing abundance of Her2, IGF-1R, and $E R \alpha$ from $50 \mu \mathrm{g}$ whole lysates of T47D and secreted IGFBP-2 in the supernatants (A), following EGCG treatment $(0-1 \mu \mathrm{M})$ for $48 \mathrm{~h}$. $\beta$-actin was assessed to show equal loading of the protein. IGFBP-2 secretion was assessed with $30 \mu$ un-concentrated supernatant. They are representative blots of experiments repeated at least three times. Fold changes of the proteins were shown by densitometry measurements (B). Sensitivity of the T47D cells to tamoxifen or herceptin (C) was determined by seeding cells $\left(0.025 \times 10^{6}\right)$ in 24-well plates in GM $24 \mathrm{~h}$ before they were placed into SFM for a further $24 \mathrm{~h}$, then treated with $1 \mu \mathrm{M}$ EGCG. One micromolar tamoxifen (TAM) or $10 \mu \mathrm{g} / \mathrm{ml}$ herceptin (Her) were dosed to cells at $48 \mathrm{~h}$ after EGCG treatment. DNA synthesis was measured using tritiated thymidine incorporation assay after $48 \mathrm{~h}$ of TAM/Her treatment. Graphs show the mean value of DPM from at least three experiments each performed in triplicate upon which statistical analysis was performed; ${ }^{*} p<0.05,{ }^{* *} p<0.01$.
(Figure 3A), but the abundance of IGF-IR protein was not affected (Figure 3A). The ER $\alpha$, Her2, and IGFBP-2 expression was increased with $1 \mu \mathrm{M}$ EGCG by $1.6(p<0.001), 2.23(p<0.02)$, and $2.06(p<0.05)$ fold, respectively (Figure 3B).

As shown in Figure 1, while low concentrations of EGCG alone caused growth inhibition in the MCF7 cells, it had little effect in T47D cells. Compared to MCF7 cells, T47D express lower levels of the ER $\alpha$ and are less responsive to TAM treatment. With low expression of Her2, monoclonal antibodies targeting Her2, such as herceptin, are also not particularly effective in blocking cell proliferation in these cells. As an increased expression of the ER $\alpha$ and Her2 was observed in T47D cells in response to EGCG, we further examined whether the sensitivity of these cells to TAM and herceptin could be improved when they were combined with $1 \mu \mathrm{M}$ EGCG.

Tamoxifen alone inhibited cell growth in T47D cells by $42 \%$, $1 \mu \mathrm{M}$ of EGCG did not cause significant growth inhibition in these cells as we saw previously, but combining both together gave a $52 \%$ decrease in cell growth, which was higher than each of them separately $(p<0.05)$ (Figure 3C). This implies that in T47D cells, EGCG synergistically enhanced their sensitivity to TAM probably due to elevated ER $\alpha$ expression. Although T47D cells express relatively low levels of the Her2 receptor, they still responded to herceptin with 28 and $23 \%$ inhibition of cell growth with or 
without EGCG treatment, respectively, which was not significantly changed.

\section{TREATMENT WITH EGCG CHANGED THE EXPRESSION OF KEY PROTEINS INVOLVED IN CELL GROWTH IN MCF7 CELLS}

Physiological concentrations of EGCG decreased cell proliferation in MCF7 cells (Figure 1A). Her2 and IGF-1R were not changed (Figure 4A), but the ER $\alpha$ and IGFBP-2 abundance decreased to $45 \%(p<0.002)$ and $44 \%(p=0.02)$ of the untreated control, respectively (Figures 4 A,B).

The tumor suppressor gene p53 is mutated in T47D and MDAMB-231 cells and has lost its function $(26,27)$. In contrast MCF7 cells possess wild-type P53 which acts as a tumor suppressor gene by playing a role in maintaining genetic integrity (28). A dosedependent increase in p53 and its downstream effector p21 was observed (Figure 4A) with a $3(p<0.001)$ and $3.5(p<0.02)$ fold increase with $1 \mu \mathrm{M}$ EGCG, respectively (Figure 4C).

\section{EGCG AT PHYSIOLOGICAL CONCENTRATIONS HAD NO EFFECTS ON THE NORMAL BREAST EPITHELIAL CELLS}

In contrast to the effects seen in the cancer cells exposed to physiological concentrations (up to $1 \mu \mathrm{M}$ ), the MCF10A cells showed no differences in cell growth (Figure 5A) or induction of cell death (Figure 5B). Consistent with the phenotype observed in

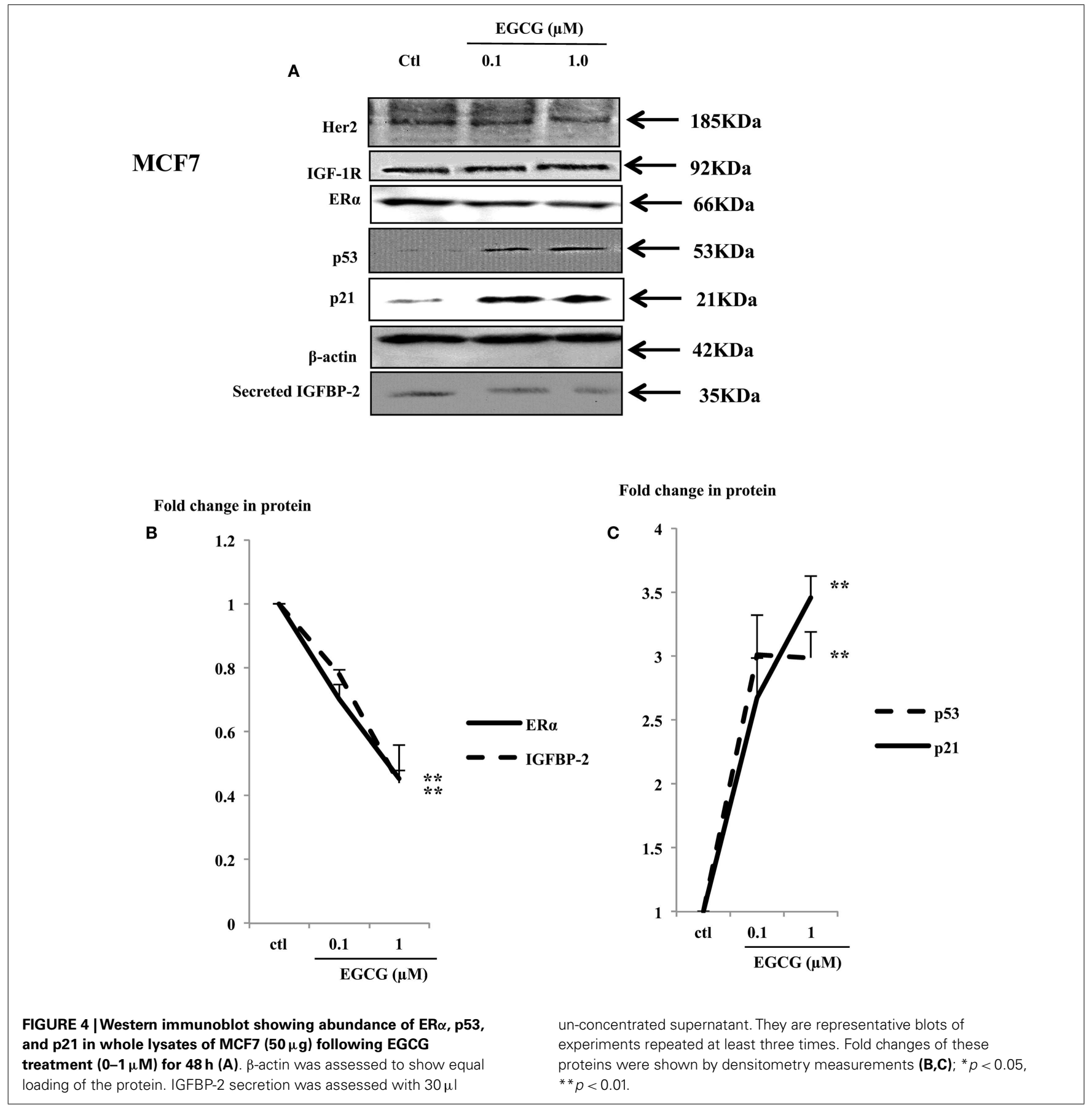



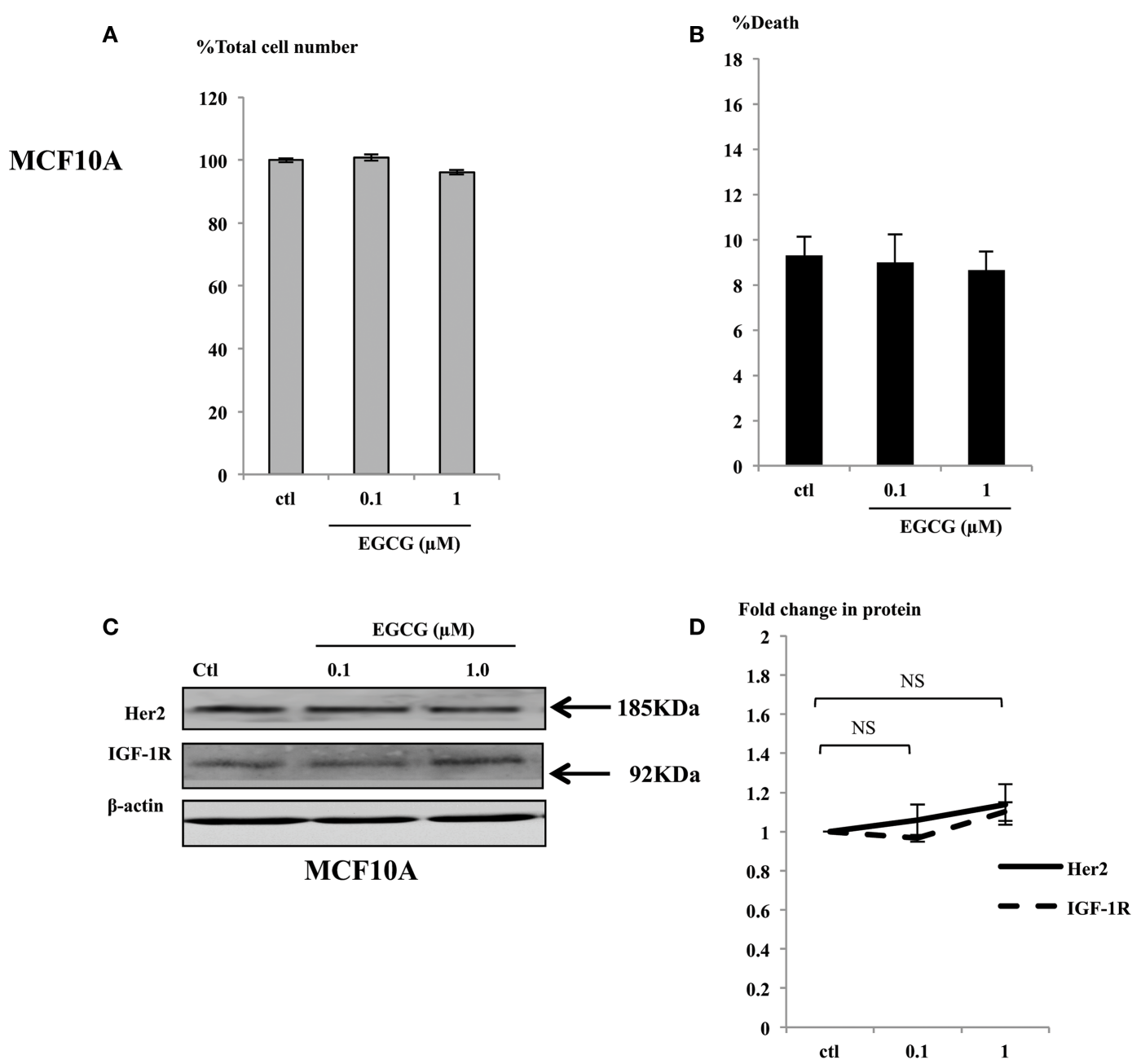

FIGURE 5 | MCF10A cells were seeded $\left(0.2 \times 10^{6}\right)$ in six-well plates in GM and after $24 \mathrm{~h}$ in SFM were dosed with EGCG (0-1 $\mu \mathrm{M})$ for $48 \mathrm{~h}$. Graphs show percentage of total cell numbers compared to the untreated control (A) and percentage of cell death (B) assessed by trypan blue exclusive cell counting. Graphs are means from at least three independent repeats, each in triplicates. Western immunoblot showing abundance of Her2 and IGF-1R in MCF10A cells with whole cell lysates $(100 \mu \mathrm{g})$ following EGCG treatment $(0-1 \mu \mathrm{M})$ for $48 \mathrm{~h}$ (C). $\beta$-actin was assessed to show equal loading of the protein. They are representative blots of experiments repeated at least three times. Fold changes of these proteins were shown by densitometry measurements (D). the non-malignant MCF10A breast cells, the expression of the key proteins involved in breast cell proliferation, such as IGF-1R and Her2 were analyzed in whole cell lysates of MCF10A cells treated with EGCG and were found not to change (Figures 5C,D). Other key proteins such as the ER $\alpha$ and IGFBP-2 were also unchanged and p53 and p21 were undetectable (data not shown).

\section{DISCUSSION}

For thousands of years, green tea has been known to exert healthpromoting effects in various conditions: cancer, cardiovascular diseases, neuro-degenerative diseases, strokes, obesity, diabetes, and many viral or bacterial infections. The most abundant catechin in green tea is EGCG. Its bioactivity, stability, potential side effects, and usage in clinical trials have been widely discussed $(3,25,29)$. However the in vitro studies that endeavor to mimic in vivo effects generally used EGCG at concentrations higher than
$10 \mu \mathrm{M}$ and even as high as $200 \mu \mathrm{M}$, which are physically unachievable in the human body. Cancer-specific toxicity is a crucial element in breast cancer therapy. Many anti-cancer drugs used in the clinic are limited by their general toxic side effects (30). Physiological concentrations of EGCG in human plasma reach between 0.1 and $1 \mu \mathrm{M}$, and may approach $7 \mu \mathrm{M}$ with supplements. In order to study whether and how EGCG at a physiological achievable concentration may potentially be beneficial to breast cancer patients, we used a range of $0.1-1 \mu \mathrm{M}$ EGCG to assess its actions on breast cancer cells. The non-malignant breast epithelial cell line MCF10A was also used as a control to examine the cancer-specificity of EGCG.

The most exciting finding from this work is that physiological concentrations of EGCG exerted cancer-selective growth inhibitory and pro-apoptotic effects. It also altered the expression of many key proteins involved in cancer growth and survival, with 
no effect on these molecules in normal cells. This in turn enhanced the sensitivity of cancer cells to current therapies. Although TAM has been successfully used in ER $\alpha$-positive breast cancers, about $30 \%$ of patients are $\mathrm{ER} \alpha$ - and/or progesterone receptor (PR)negative and resistant to endocrine modification and therefore display poor prognosis. In addition, a proportion of hormone positive cancers that initially respond to hormone therapy eventually develop hormone resistance and become more aggressive. If a cancer also lacks Her2 expression, they are described as being triple negative (TNBC). MDA-MB-231 is an example of a TNBC cell line which lacks $\mathrm{ER} \alpha, \mathrm{PR}$, and Her2 expression and is resistant to hormone therapy.

With MDA-MB-231, we found the induction of cell death was a dominant consequence of EGCG treatment by itself. In addition, EGCG also increased ER $\alpha$ abundance in these cells and as a result of this, the cells were then able to respond to TAM.

Chrisholm et al. also showed cytotoxic effects of EGCG alone in another $\mathrm{ER} \alpha$-negative breast cancer cell line, Hs578T and a synergistic cytotoxic effect of EGCG with TAM in MDA-MB-231 cells (31), but at much higher, non-physiological concentrations.

Various studies using EGCG found that it regulated tumor suppressor genes through DNA demethylation $(32,33)$ or histone re-acetylation in skin (34), breast (35), prostate (36), colon, and esophageal cancer (37). In the ER $\alpha$-negative MDA-MB-231 cells, it was reported that EGCG re-activated ER $\alpha$ expression at $10 \mu \mathrm{M}$ and synergistically regulated $\mathrm{ER} \alpha$ re-expression with AZA and TSA (19). The modulation of the chromatin markers including acetyl$\mathrm{H} 3$, acetyl-H3K9, acetyl-H4, dimethyl-H3K4, and trimethyl-H3K9 indicated epigenetic regulation by EGCG in MDA-MB-231 cells. It is also suggested that histone modification mechanisms may play a more important role in EGCG-induced-ER $\alpha$ reactivation than DNA methylation in ER $\alpha$-negative breast cancer cells. Our data also show that EGCG re-expressed the ER $\alpha$ but at physiological concentrations. Examining if this is by the same epigenetic mechanism would be interesting as this would more easily be translated into the clinic. In addition, we found that the MDAMB-231 cells were still unable to respond to exogenous estradiol despite re-expression of the $\mathrm{ER} \alpha$ (data not shown).

Unlike the data from Chrisholm et al., who did not observe growth inhibitory effects of EGCG in ER $\alpha$-positive breast cancer cells (31), we found EGCG alone at physiological levels did have inhibitory actions on cell growth in MCF7 cells. The tumor suppressor gene p53 is mutated in T47D and MDA-MB-231 cells and has lost its function $(26,27)$. But wild-type p53 is present in MCF7 cells and acts as a tumor suppressor gene by playing a role in maintaining genetic integrity (28). A dose-dependent decrease in $\mathrm{ER} \alpha$ abundance together with an increase in p53 and p21 in response to EGCG may contribute to the decreased cell proliferation. These results are consistent with a report from Liang et al. (38), in which $30 \mu \mathrm{M}$ EGCG caused an accumulation of p53, p21, and p27 in MCF7 cells, which was purported to contribute to EGCG-induced cell cycle G1 arrest. Our new data suggest that even very low, physiological concentrations of EGCG can simulate changes in abundance of key anti-proliferative proteins that leads to inhibition of cell growth. Very recently, an EGCG-induced decease of $\mathrm{ER} \alpha$ transcription and expression in $\mathrm{ER} \alpha$-positive breast cancer cells MCF7 and T47D at the promoter activity level has been reported (39). However, non-physiological concentrations of EGCG were used ( $20 \mu \mathrm{M}$ and above). It will be interesting to investigate if the same mechanism underlies the changes of $\mathrm{ER} \alpha$ protein expression in MCF7 observed in our study using achievable concentrations of EGCG. We and others have found that the demethylating agent AZA induced a similar down-regulation of $\mathrm{ER} \alpha$ in the ER $\alpha$-positive breast cancer cell lines MCF7 and T47D, but not via epigenetic modulation $(40,41)$.

Using physiologically doses with T47D cells, we found that in contrast to MCF7 cells, EGCG actually caused an increase in abundance of the ER $\alpha$. In these cells, the growth inhibition was unaffected by low doses of EGCG, but having observed that EGCG increased the ER $\alpha$ abundance, we combined treatment of EGCG with TAM, which targets $\mathrm{ER} \alpha$ and observed an additive growth inhibition but reassuringly the increase in the ER $\alpha$ was not accompanied by an enhanced proliferative response to estradiol (data not shown).

Although $\mathrm{ER} \alpha$ is the main driver of breast cancer progression and still the main target for treatment, dysregulation of the IGF1R/phosphatidylinositol-3-kinase (PI3K)/Akt pathway has been shown to correlate with breast cancer development and has been intensively studied as a potential therapeutic target (42-44). The trans-membrane receptor IGF-IR is a tyrosine kinase receptor and mediates insulin-like growth factor (IGF) activities. Increased levels of the IGF-IR have been implicated in many cancers including breast (42) and prostate cancer (45). IGF-IR signaling stimulates cell growth and inhibits death (46). Among different potential approaches to treat TNBC, some small molecular inhibitors or neutralizing antibodies targeting IGF-IR have been designed to block IGF-IR pathway and therefore to reduce cancer cell growth. $\alpha$ IR3 is a monoclonal antibody that acts as an IGF-IR antagonist (47). Blockade of tumor growth in vivo and in vitro has been observed with treatment of $\alpha$ IR3 in MDA-MB-231 cells (48). We have shown here that with MDA-MB-231 cells, physiological concentrations of EGCG increase the IGF-IR and improve their response to $\alpha I R 3$. Since clinically the TNBC are difficult to treat, the significant enhancement of low concentrations of EGCG on the cells response to $\alpha$ IR3 may be clinically very relevant. Particularly, we found that the response of the cells to IGF-I was not increased by EGCG despite the observed increase in levels of the receptor. As MDA-MB-231 cells produce a significant amount of endogenous IGF-II, we speculate that this amount of peptide could saturate the IGF-IR present on these cells and hence why addition of exogenous IGF-I has no further effect on cell proliferation. However, $\alpha$ IR 3 would be able to compete with the endogenous IGF-II and to inhibit the cell growth but this mechanism remains to be confirmed.

We recently showed that IGFBP-2 is a novel positive regulator of the ER $\alpha$ and that this promotes cell survival in ER $\alpha$-positive breast cancer cells (49). We confirmed in this study that the ability of EGCG to increase ER $\alpha$ was associated with an increase in IGFBP-2 and a reduction of $\mathrm{ER} \alpha$ corresponded to a reduction of IGFBP-2. It will be interesting to investigate further the role of EGCG-induced changes of IGFBP-2 in breast cancer.

Having examined key molecules that have been implicated in regulating breast cancer cell growth and survival, we found no consistent changes that would explain the uniform inhibitory effects of 
EGCG. The ER $\alpha$, Her2, and IGF-1R pathways contribute to different extents in the different cell lines that have varying phenotypes and some of the changes that we observed may have contributed to the effects of EGCG or they could have been compensatory responses.

Compared to in vivo conditions, cells in vitro are exposed to EGCG for very short time (only $48 \mathrm{~h}$ ). We acknowledge that over this short period we have observed relatively small changes although significant, but presumably continuous longterm repeated exposure of cells in vivo to EGCG may have a more marked cumulative effect.

To promote safety and effectiveness of dietary reagents, derivatives with structural modifications such as pEGCG have been developed and synthesized. With changed structural characteristics, these phenolic compounds exert enhanced anti-proliferative effects in cancers (18). A nanoparticle-encapsulating EGCG has also been designed for oral administration in mice with human prostate cancer $(50,51)$. Our study highlights that the impact and specificity of EGCG in cells seems to be concentration-related and further studies investigating the effects of physiological levels of EGCG are essential.

\section{REFERENCES}

1. Lecumberri E, Dupertuis YM, Miralbell R, Pichard C. Green tea polyphenol epigallocatechin-3-gallate (EGCG) as adjuvant in cancer therapy. Clin Nutr (2013) 32(6):894-903. doi:10.1016/j.clnu.2013.03.008

2. Yang CS, Maliakal P, Meng X. Inhibition of carcinogenesis by tea. Annu Rev Pharmacol Toxicol (2002) 42:25-54. doi:10.1146/annurev.pharmtox.42.082101. 154309

3. Surh YJ. Cancer chemoprevention with dietary phytochemicals. Nat Rev Cancer (2003) 3(10):768-80. doi:10.1038/nrc1189

4. Yang CS, Li G, Yang Z, Guan F, Chen A, Ju J. Cancer prevention by tocopherols and tea polyphenols. Cancer Lett (2013) 334(1):79-85. doi:10.1016/j.canlet. 2013.01.051

5. Benson JR, Jatoi I. The global breast cancer burden. Future Oncol (2012) 8(6):697-702. doi:10.2217/fon.12.61

6. Lambert JD, Yang CS. Cancer chemopreventive activity and bioavailability of tea and tea polyphenols. Mutat Res (2003) 52(3-524):201-8. doi:10.1016/S00275107(02)00336-6

7. Lee MJ, Wang ZY, Li H, Chen L, Sun Y, Gobbo S, et al. Analysis of plasma and urinary tea polyphenols in human subjects. Cancer Epidemiol Biomarkers Prev (1995) 4(4):393-9.

8. Zhou DH, Wang X, Yang M, Shi X, Huang W, Feng Q. Combination of low concentration of (-)-epigallocatechin gallate (EGCG) and curcumin strongly suppresses the growth of non-small cell lung cancer in vitro and in vivo through causing cell cycle arrest. Int J Mol Sci (2013) 14(6):12023-36. doi:10.3390/ ijms140612023

9. Relat J, Blancafort A, Oliveras G, Cufi S, Haro D, Marrero PF, et al. Different fatty acid metabolism effects of (-)-epigallocatechin-3-gallate and C75 in adenocarcinoma lung cancer. BMC Cancer (2012) 12:280. doi:10.1186/1471-2407-12-280

10. Chuu CP, Chen RY, Kokontis JM, Hiipakka RA, Liao S. Suppression of androgen receptor signaling and prostate specific antigen expression by (-)epigallocatechin-3-gallate in different progression stages of LNCaP prostate cancer cells. Cancer Lett (2009) 275(1):86-92. doi:10.1016/j.canlet.2008.10.001

11. Sanchez-Tena S, Vizan P, Dudeja PK, Centelles JJ, Cascante M. Green tea phenolics inhibit butyrate-induced differentiation of colon cancer cells by interacting with monocarboxylate transporter 1. Biochim Biophys Acta (2013) 1832(12):2264-70. doi:10.1016/j.bbadis.2013.08.009

12. Singh T, Katiyar SK. Green tea polyphenol, (-)-epigallocatechin-3-gallate, induces toxicity in human skin cancer cells by targeting beta-catenin signaling. Toxicol Appl Pharmacol (2013) 273(2):418-24. doi:10.1016/j.taap.2013.09.021

13. Belguise K, Guo SQ, Sonenshein GE. Activation of FOXO3a by the green tea polyphenol epigallocatechin-3-gallate induces estrogen receptor alpha expression reversing invasive phenotype of breast cancer cells. Cancer Res (2007) 67(12):5763-70. doi:10.1158/0008-5472.CAN-06-4327

14. Sen T, Dutta A, Chatterjee A. Epigallocatechin-3-gallate (EGCG) downregulates gelatinase-B (MMP-9) by involvement of FAK/ERK/NFkappaB and AP-1 in the human breast cancer cell line MDA-MB-231. Anticancer Drugs (2010) 21(6):632-44. doi:10.1097/CAD.0b013e32833a4385

15. Gu JW, Makey KL, Tucker KB, Chinchar E, Mao X, Pei I, et al. EGCG, a major green tea catechin suppresses breast tumor angiogenesis and growth via inhibiting the activation of HIF-1alpha and NFkappaB, and VEGF expression. Vasc Cell (2013) 5(1):9. doi:10.1186/2045-824X-5-9

16. Li Y, Tollefsbol TO. Impact on DNA methylation in cancer prevention and therapy by bioactive dietary components. Curr Med Chem (2010) 17(20):2141-51. doi:10.2174/092986710791299966

17. Siddiqui IA, Asim M, Hafeez BB, Adhami VM, Tarapore RS, Mukhtar H. Green tea polyphenol EGCG blunts androgen receptor function in prostate cancer. FASEB J (2011) 25(4):1198-207. doi:10.1096/fj.10-167924

18. Meeran SM, Patel SN, Chan TH, Tollefsbol TO. A novel prodrug of epigallocatechin-3-gallate: differential epigenetic hTERT repression in human breast cancer cells. Cancer Prev Res (2011) 4(8):1243-54. doi:10.1158/19406207.CAPR-11-0009

19. Li Y, Yuan YY, Meeran SM, Tollefsbol TO. Synergistic epigenetic reactivation of estrogen receptor-alpha (ERalpha) by combined green tea polyphenol and histone deacetylase inhibitor in ERalpha-negative breast cancer cells. Mol Cancer (2010) 9:274. doi:10.1186/1476-4598-9-274

20. Thomas F, Holly JM, Persad R, Bahl A, Perks CM. Fibronectin confers survival against chemotherapeutic agents but not against radiotherapy in DU145 prostate cancer cells: involvement of the insulin like growth factor-1 receptor. Prostate (2010) 70(8):856-65. doi:10.1002/pros.21119

21. Davies SC, Holly JM, Coulson VJ, Cotterill AM, Abdulla AF, Whittaker PG, et al. The presence of cation-dependent proteases for insulin-like growth factor binding proteins does not alter the size distribution of insulin-like growth factors in pregnancy. Clin Endocrinol (1991) 34(6):501-6. doi:10.1111/j.1365-2265.1991. tb00331.x

22. Yang CS, Chen L, Lee MJ, Balentine D, Kuo MC, Schantz SP. Blood and urine levels of tea catechins after ingestion of different amounts of green tea by human volunteers. Cancer Epidemiol Biomarkers Prev (1998) 7(4):351-4.

23. Umegaki K, Sugisawa A, Yamada K, Higuchi M. Analytical method of measuring tea catechins in human plasma by solid-phase extraction and HPLC with electrochemical detection. J Nutr Sci Vitaminol (2001) 47(6):402-8. doi:10.3177/jnsv.47.402

24. Lambert JD, Yang CS. Mechanisms of cancer prevention by tea constituents. J Nutr (2003) 133(10):3262S-7S.

25. Howells LM, Moiseeva EP, Neal CP, Foreman BE, Andreadi CK, Sun YY, et al. Predicting the physiological relevance of in vitro cancer preventive activities of phytochemicals. Acta Pharmacol Sin (2007) 28(9):1274-304. doi:10.1111/j. 1745-7254.2007.00690.x

26. Lim LY, Vidnovic N, Ellisen LW, Leong CO. Mutant p53 mediates survival of breast cancer cells. Br J Cancer (2009) 101(9):1606-12. doi:10.1038/sj.bjc. 6605335

27. Hui L, Zheng Y, Yan Y, Bargonetti J, Foster DA. Mutant p53 in MDA-MB231 breast cancer cells is stabilized by elevated phospholipase D activity and contributes to survival signals generated by phospholipase D. Oncogene (2006) 25(55):7305-10. doi:10.1038/sj.onc.1209735

28. Barnes DM, Camplejohn RS. P53, apoptosis, and breast cancer. J Mammary Gland Biol Neoplasia (1996) 1(2):163-75. doi:10.1007/BF02013640

29. Mereles D, Hunstein W. Epigallocatechin-3-gallate (EGCG) for clinical trials: more pitfalls than promises? Int J Mol Sci (2011) 12(9):5592-603. doi:10.3390/ ijms12095592

30. Chari RV. Targeted cancer therapy: conferring specificity to cytotoxic drugs. Acc Chem Res (2008) 41(1):98-107. doi:10.1021/ar700108g

31. Chisholm K, Bray BJ, Rosengren RJ. Tamoxifen and epigallocatechin gallate are synergistically cytotoxic to MDA-MB-231 human breast cancer cells. Anticancer Drug (2004) 15(9):889-97. doi:10.1097/00001813-200410000-00010

32. Schramm L. Going green: the role of the green tea component EGCG in chemoprevention. J Carcinog Mutagen (2013) 4(142):1000142. doi:10.4172/2157-2518. 1000142

33. Fang MZ, Chen DP, Yang CS. Dietary polyphenols may affect DNA methylation. J Nutr (2007) 137(1):223s-8s. 
34. Nandakumar V, Vaid M, Katiyar SK. (-)-Epigallocatechin-3-gallate reactivates silenced tumor suppressor genes, Cip1/p21 and p16INK4a, by reducing DNA methylation and increasing histones acetylation in human skin cancer cells. Carcinogenesis (2011) 32(4):537-44. doi:10.1093/carcin/bgq285

35. Berletch JB, Liu C, Love WK, Andrews LG, Katiyar SK, Tollefsbol TO. Epigenetic and genetic mechanisms contribute to telomerase inhibition by EGCG. J Cell Biochem (2008) 103(2):509-19. doi:10.1002/jcb.21417

36. Bhatia N, Agarwal R. Detrimental effect of cancer preventive phytochemicals silymarin, genistein and epigallocatechin 3-gallate on epigenetic events in human prostate carcinoma DU145 cells. Prostate (2001) 46(2):98-107. doi:10.1002/1097-0045(20010201)46:2<98::AID-PROS1013>3.3.CO;2-B

37. Fang MZ, Wang Y, Ai N, Hou Z, Sun Y, Lu H, et al. Tea polyphenol (-)-epigallocatechin-3-gallate inhibits DNA methyltransferase and reactivates methylation-silenced genes in cancer cell lines. Cancer Res (2003) 63(22):7563-70.

38. Liang YC, Lin-Shiau SY, Chen CF, Lin JK. Inhibition of cyclin-dependent kinases 2 and 4 activities as well as induction of Cdk inhibitors p21 and p27 during growth arrest of human breast carcinoma cells by (-)-epigallocatechin-3-gallate. J Cell Biochem (1999) 75(1):1-12. doi:10.1002/(SICI)1097-4644(19991001)75: $1<1:$ AID-JCB1 > 3.0.CO;2-N

39. De Amicis F, Russo A, Avena P, Santoro M, Vivacqua A, Bonofiglio D, et al. In vitro mechanism for downregulation of ER-alpha expression by epigallocatechin gallate in ER+/PR+ human breast cancer cells. Mol Nutr Food Res (2013) 57(5):840-53. doi:10.1002/mnfr.201200560

40. Zeng L, Jarrett C, Brown K, Gillespie KM, Holly JM, Perks CM. Insulin-like growth factor binding protein-3 (IGFBP-3) plays a role in the anti-tumorigenic effects of 5-Aza-2'-deoxycytidine (AZA) in breast cancer cells. Exp Cell Res (2013) 319(14):2282-95. doi:10.1016/j.yexcr.2013.06.011

41. Pryzbylkowski P, Obajimi O, Keen JC. Trichostatin A and 5 Aza-2' deoxycytidine decrease estrogen receptor mRNA stability in ER positive MCF7 cells through modulation of HuR. Breast Cancer Res Treat (2008) 111(1):15-25. doi:10.1007/s10549-007-9751-0

42. Chang WW, Lin RJ, Yu J, Chang WY, Fu CH, Lai AC, et al. The expression and significance of insulin-like growth factor-1 receptor and its pathway on breast cancer stem/progenitors. Breast Cancer Res (2013) 15(3):R39. doi:10.1186/bcr3423

43. Fu X, Osborne CK, Schiff R. Biology and therapeutic potential of PI3K signaling in ER+/HER2-negative breast cancer. Breast (2013) 22(Suppl 2):S12-8. doi:10.1016/j.breast.2013.08.001

44. Van Aller GS, Carson JD, Tang W, Peng H, Zhao L, Copeland RA, et al. Epigallocatechin gallate (EGCG), a major component of green tea, is a dual
phosphoinositide-3-kinase/mTOR inhibitor. Biochem Biophys Res Commun (2011) 406(2):194-9. doi:10.1016/j.bbrc.2011.02.010

45. Gunter JH, Sarkar PL, Lubik AA, Nelson CC. New players for advanced prostate cancer and the rationalisation of insulin-sensitising medication. Int J Cell Biol (2013) 2013:834684. doi:10.1155/2013/834684

46. Chitnis MM, Yuen JS, Protheroe AS, Pollak M, Macaulay VM. The type 1 insulinlike growth factor receptor pathway. Clin Cancer Res (2008) 14(20):6364-70. doi:10.1158/1078-0432.CCR-07-4879

47. Riedemann J, Macaulay VM. IGF1R signalling and its inhibition. Endocr Relat Cancer (2006) 13(Suppl 1):S33-43. doi:10.1677/erc.1.01280

48. Arteaga CL. Interference of the IGF system as a strategy to inhibit breast cancer growth. Breast Cancer Res Treat (1992) 22(1):101-6. doi:10.1007/BF01833338

49. Foulstone EJ, Zeng L, Perks CM, Holly JM. Insulin-like growth factor binding protein 2 (IGFBP-2) promotes growth and survival of breast epithelial cells: novel regulation of the estrogen receptor. Endocrinology (2013) 154(5):1780-93. doi:10.1210/en.2012-1970

50. Khan N, Bharali DJ, Adhami VM, Siddiqui IA, Cui H, Shabana SM, et al. Oral administration of naturally occurring chitosan based nanoformulated green tea polyphenol EGCG effectively inhibits prostate cancer cell growth in a xenograft model. Carcinogenesis (2013) 35(2):415-23. doi:10.1093/carcin/bgt321

51. de Pace RC, Liu X, Sun M, Nie S, Zhang J, Cai Q, et al. Anticancer activities of (-)epigallocatechin-3-gallate encapsulated nanoliposomes in MCF7 breast cancer cells. J Liposome Res (2013) 23(3):187-96. doi:10.3109/08982104.2013.788023

Conflict of Interest Statement: The authors declare that the research was conducted in the absence of any commercial or financial relationships that could be construed as a potential conflict of interest.

Received: 21 February 2014; accepted: 13 April 2014; published online: 07 May 2014. Citation: Zeng L, Holly JMP and Perks CM (2014) Effects of physiological levels of the green tea extract epigallocatechin-3-gallate on breast cancer cells. Front. Endocrinol. 5:61. doi: 10.3389/fendo.2014.00061

This article was submitted to Cancer Endocrinology, a section of the journal Frontiers in Endocrinology.

Copyright (c) 2014 Zeng, Holly and Perks. This is an open-access article distributed under the terms of the Creative Commons Attribution License (CC BY). The use, distribution or reproduction in other forums is permitted, provided the original author(s) or licensor are credited and that the original publication in this journal is cited, in accordance with accepted academic practice. No use, distribution or reproduction is permitted which does not comply with these terms. 